Transactions of the American Fisheries Society 1998, v.127, n.6, pp.1021-1039.

Online ISSN: $1548-8659$

Print ISSN: 0002-8487

http://afs.allenpress.com/perlserv/?request=get-archive

http://afsjournals.org/doi/pdf/10.1577/1548-8659(1998)127\%3C1021\%3ACBLFIR\%3E2.0.CO\%3B2

c) Copyright by the American Fisheries Society 1998. 


\title{
Competition between Larval Fishes in Reservoirs: The Role of Relative Timing of Appearance
}

\author{
James E. GarveY*1 And Roy A. Stein \\ Aquatic Ecology Laboratory, Department of Zoology, The Ohio State University \\ 1314 Kinnear Road, Columbus, Ohio 43212-1194, USA
}

\begin{abstract}
In small, hypereutrophic reservoirs ( $<100 \mathrm{ha} ;>100 \mu \mathrm{g}$ total phosphorus/L), larval gizzard shad Dorosoma cepedianum and threadfin shad D. petenense (henceforth, shad) reach high densities in the limnetic zone, virtually eliminate zooplankton, and perhaps compromise success of other planktivorous larvae, such as bluegill Lepomis macrochirus. Because relative timing of appearance of shad and bluegills probably influences their relative success, we quantified densities of fish larvae and zooplankton during spring through summer in three reservoirs across 8 years (1987-1994), and we conducted three hatchery experiments with varying larval appearance times and gizzard shad densities in plastic bags $\left(1 \mathrm{~m}^{3}\right)$. When shad were abundant in reservoirs, bluegill abundance often peaked either at the same time (36\% of reservoirs and years combined) or after ( $40 \%$ of reservoirs and years combined) shad peaks. When gizzard shad were placed in bags 2 weeks before bluegills $(N=1$ experiment), they depleted zooplankton, reducing growth $(\sim 0.075$ $\left.\mathrm{g} \cdot \mathrm{g}^{-1} \cdot \mathrm{d}^{-1}\right)$ but not survival of bluegills. In experiments $(N=2)$ in which both species were added simultaneously, zooplankton declined only slightly with gizzard shad, and there was little effect on bluegill growth $\left(\sim 0.21 \mathrm{~g} \cdot \mathrm{g}^{-1} \cdot \mathrm{d}^{-1}\right)$ and survival; in general, gizzard shad growth declined with time and increasing gizzard shad density. Based on experiments, bluegill success should vary among reservoirs and years as a function of their appearance relative to gizzard shad. In reservoirs, zooplankton availability and bluegill abundances were consistently low during years when gizzard shad dominated reservoir fish assemblages. Because gizzard shad probably reduce bluegill success in hypereutrophic Ohio reservoirs, management strategies that reduce gizzard shad should improve bluegill success.
\end{abstract}

\section{Introduction}

For many fishes, survival during the larval and juvenile stages varies tremendously, rendering predictions for their recruitment to older life stages difficult unless underlying processes are understood (Blaxter 1974; Miller et al. 1988; Frank and Leggett 1994; Leggett and DeBlois 1994). Competition has long been recognized as a factor influencing distribution and abundance of adults (Connell 1983; Schoener 1983) and may play a crucial role during early life stages (DeVries et al. 1991). Larval and juvenile fish often compete with same-aged or earlier-hatched cohorts (Werner and Blaxter 1980; Buynak et al. 1992; Kneib 1993; Welker et al. 1994), as well as with adults and juveniles of other species (Gilliam 1982; Crowder and Crawford 1984; Persson 1988; Persson and Greenberg 1990; Prout et al. 1990; Olson et al. 1995), for limited food. As a consequence, slowgrowing larvae can suffer increased mortality due to starvation (Werner and Blaxter 1980; Kashuba and Matthews 1984; Letcher et al. 1996) and predation (Hunter 1981; Blaxter 1986; Rice et al.

\footnotetext{
* Corresponding author: jgarvey@ksu.edu

${ }^{1}$ Present address: Division of Biology, Ackert Hall, Kansas State University, Manhattan, Kansas 66506, USA.
}

1987; Luecke et al. 1990; Duffy et al. 1996). Because the intensity of competition may drive the extent of larval survival, variable competition among systems and across years should influence variability in year-class strength.

In many organisms, relative hatch timing influences their overlap in space and time with cooccurring species and thus the extent of their competitive interactions (Alford and Wilbur 1985; Sredl and Collins 1991; Hodge et al. 1996). Productive warmwater reservoirs in the eastern United States often contain abundant gizzard shad Dorosoma cepedianum, a species that produces high densities of offspring (>60-100 larvae/ $\mathrm{m}^{3}$; DeVries and Stein 1992; Dettmers and Stein 1992, 1996; Welker et al. 1994) in the limnetic zone during early spring. Juvenile $(\sim 25 \mathrm{~mm}$ total length, TL) gizzard shad and a congener, threadfin shad $D$. petenense, can deplete zooplankton within 1-3 weeks of reaching peak densities in spring (Ziebell et al. 1986; DeVries et al. 1991; DeVries and Stein 1992; Dettmers and Stein 1996) and then escape intraspecific competition by switching to detritivory (Stein et al. 1995). Gizzard shad can appear early relative to other species with obligate limnetic larvae, such as bluegill Lepomis macrochirus (DeVries and Stein 1992; Welker et al. 
1994), potentially reducing growth and survival of these sympatric species via exploitative competition (Jenkins 1955; Davies et al. 1979; Kirk et al. 1986; Guest et al. 1990; DeVries et al. 1991; DeVries and Stein 1992; Garvey et al. 1998a).

Although densities of shad and other fishes with planktivorous larvae are often negatively related, effects of these shad species can be equivocal (DeVries and Stein 1990; Pope and DeVries 1994; Welker et al. 1994), suggesting that their negative effects on other species vary among systems and years. Relative timing of appearance and peak densities of larvae may contribute to variable competitive interactions (Pope and DeVries 1994). Indeed, abiotic effects such as water level fluctuations and temperature (Michaletz 1997), as well as productivity and turbidity (Stein et al. 1996; Bremigan 1997), apparently influence timing of appearance, abundance, and size of threadfin shad and gizzard shad larvae, intensifying or mitigating interspecific competition for zooplankton. Because relative timing of shad larvae and other sympatric species has been quantified in relatively few systems during only 1-2 years, little is known about the extent of temporal overlap of larvae among reservoirs and years and how variable timing of appearance might influence competitive interactions.

Because both density and variable appearance times of threadfin and gizzard shad might influence availability of zooplankton for bluegills, we quantified densities of these larval and juvenile fishes and their zooplankton prey during spring through summer in three small Ohio reservoirs $(<100$ ha) across 8 years (1987-1994). To explore competitive effects in a controlled setting, we also conducted enclosure experiments (1992, 1994, 1995) to quantify how timing of appearance of gizzard shad and bluegills in enclosures, as well as gizzard shad density, influence their growth and survival.

\footnotetext{
Methods

\section{Reservoir Sampling}

To explore how differences in timing of appearance of threadfin shad, gizzard shad, and bluegills in the limnetic zone affect exploitative competition for zooplankton, we quantified densities of zooplankton, age-0 threadfin shad, age-0 gizzard shad, and age- 0 bluegills in three hypereutrophic (100-350 $\mu \mathrm{g}$ total phosphorus/L; Bremigan 1997) and turbid (Secchi depths, 0.3-0.5 m) Ohio reservoirs during April through August 1987-1994. Kokosing Lake (Knox County; 65 ha)
}

always contained gizzard shad. As part of a study exploring the influence of stocked threadfin shad as supplemental forage for piscivorous sportfish, two reservoirs, Clark Lake (Clark County; 40 ha) and Stonelick Lake (Clermont County; 69 ha), were stocked with adult threadfin shad and, apparently, a small number of gizzard shad in 1988 (DeVries et al. 1991; Bremigan et al. 1991). By 1990, gizzard shad was the only shad species in these reservoirs (Bremigan et al. 1991; Garvey et al. 1998a). In all reservoirs, limnetic threadfin shad, gizzard shad, and bluegill larvae $(<25 \mathrm{~mm}$ TL) were sampled once every week during April through early July and once every 2 weeks thereafter with a 0.75 -m-diameter, 500- $\mu \mathrm{m}$ mesh net towed at $1-1.5 \mathrm{~m} / \mathrm{s}$ at sites near the $\operatorname{dam}(N=2$ tows/date). Volume of water sampled was quantified with an attached flowmeter. Larval fish were preserved in $95 \%$ ethanol, identified to species, and counted to estimate number of age- $0 \mathrm{fish} / \mathrm{m}^{3}$ (as per Stahl and Stein 1994).

On each sampling date, we collected zooplankton at three (Clark Lake and Kokosing Lake) to five (Stonelick Lake) stations: one upstream site, one to three midreservoir sites, and one downstream (dam) site. Zooplankton was either collected with a clear Lexan tube sampler $(7.3 \mathrm{~cm}$ diameter; 1987-1992; see DeVries and Stein 1991) plus a $54-\mu \mathrm{m}$ sieve or a $0.3-\mathrm{m}$-diameter net (54$\mu \mathrm{m}$ mesh) towed from the bottom to the surface (1993-1994) and preserved in 70\% ethanol. To quantify densities of zooplankton, we identified cladocerans to genus and copepods as calanoids, cyclopoids, or nauplii. Rotifers were not counted (henceforth, zooplankton refers to crustacean zooplankton only). For abundant taxa, a minimum of 50 individuals/sample were counted from a wellmixed subsample. For rare taxa, we counted one eighth of the sample. If we calculated that the total number of individuals within a sample was 25 or less, we discontinued sampling. If we estimated more than 25 individuals/sample from that eighth, we continued counting until either 50 individuals or the entire sample was counted (Stahl and Stein 1994). Because nets, relative to tube samplers, underestimate zooplankton densities (DeVries and Stein 1991), we adjusted total density estimates (number/L) from nets to those in tubes by multiplying net densities by 1.7 (DeVries and Stein 1991).

Peak densities of larvae reflect the potential maximum number of juveniles produced (Mooij 1996; Donovan et al. 1997). By understanding factors driving success of bluegills at these peaks, we 
can infer the likelihood of their survival to later juvenile stages (and thus their abundance). Hence, we quantified zooplankton densities on the dates of first appearance, as well as on the dates bluegills peaked in abundance, in each reservoir and year, assuming that zooplankton density at these times influenced successful larval growth and survival.

\section{Experiments}

General design.-To assess how relative timing of appearance as well as density of gizzard shad and bluegills influenced their interactions for zooplankton, we conducted three experiments at the Hebron State Fish Hatchery (Licking County, eastcentral Ohio) in late spring 1992, 1994, and 1995. Experimental units were 4-mil clear plastic bags $(107 \times 76 \times 178 \mathrm{~cm})$ stapled onto wooden frames affixed to a walkway in a hatchery pond (see Stahl and Stein 1994). For all three experiments, treatments were randomly assigned to bags. About 1 week before each experiment, all bags were filled with approximately $1 \mathrm{~m}^{3}$ of water sieved through a 500- $\mu \mathrm{m}$ mesh to exclude fish larvae but not zooplankton. Zooplankton also was collected from a nearby hatchery pond with a $54-\mu \mathrm{m}-\mathrm{mesh}$ net and added to bags to increase initial zooplankton densities to 400 zooplankters/L, if possible. Zooplankton was then quantified every 3-5 d during experiments with two or three $1.5-\mathrm{m}$ water columns of a tube sampler, again sieved through a 54- $\mu \mathrm{m}-$ mesh net and preserved in 70\% ethanol (see Reservoir Sampling above). In 1992, water temperatures were recorded every 3-5 d directly adjacent to bags; in 1994 and 1995, water temperatures were recorded 4-5 times daily with a temperature data logger.

Age-0 gizzard shad and bluegills for the experiments were collected from nearby ponds containing either spawning adult gizzard shad or adult bluegills. During all experiments, fish were added to bags at densities similar to those in reservoirs (see Specific experiments below) and sampled by dismantling bags through time. Dismantling included slowly pumping water from bags through a 500- $\mu \mathrm{m}$-mesh net until little water remained and then using a hand net to collect fish. Preliminary experiments revealed that handling mortality did not occur and that all fish could be recovered during dismantling (as with Stahl and Stein 1994). Fish recovered were preserved in $95 \%$ ethanol and then measured $(\mathrm{mg})$ and weighed $(0.001 \mathrm{~g})$. Digestive tracts of fish were removed; all prey were identified to genus when possible, and total biomass (dry weight, mg) was estimated by first using body dimension-dry weight relationships to calculate individual prey weights (for macroinvertebrates: Smock 1980; G. G. Mittelbach, Michigan State University, unpublished data.; for zooplankton: Dumont et al. 1975, Culver et al. 1985). For each item, we measured the appropriate body dimensions (e.g., head depth, body length; measurements ranged from 0.05 to $1.5 \mathrm{~mm}$ ) required for each regression using a dissecting microscope at $25 \times$ magnification with a drawing tube and digitizing equipment (SigmaScan). We then converted these measurements to dry weight.

Specific experiments.-The three experiments were designed to explore timing and density effects on growth and survival of bluegills and gizzard shad: (1) gizzard shad were added first and then bluegills were added 2 weeks later (SEP experiment), (2) bluegills were added simultaneously with low densities of gizzard shad relative to field densities (SIM experiment), and (3) gizzard shad and bluegills were added at variable gizzard shad densities (SIMVARY experiment). These experiments are described in detail below.

In Ohio reservoirs, gizzard shad can reach peak densities 1-3 weeks before most bluegills appear (DeVries and Stein 1992; Welker et al. 1994; Stein et al. 1995; this study). During June through early July 1992, we assessed how early appearance of gizzard shad influenced growth and survival of bluegills added to bags 2 weeks later (i.e., the SEP experiment; see Table 1 for design and larval sizes; duration, $25 \mathrm{~d}$ ). To assess the effect of gizzard shad on bluegill growth, we included bluegill-only and bluegill-plus-gizzard-shad treatments (Table 1). A gizzard-shad-only treatment allowed us to assess the impact of gizzard shad on zooplankton in the absence of bluegills (Table 1). At the outset, we added gizzard shad to treatments at 20 gizzard $\mathrm{shad} / \mathrm{m}^{3}$ (i.e., 20 gizzard $\mathrm{shad} / \mathrm{bag}$ ), a fairly low density compared with those often occurring in reservoirs (Dettmers and Stein 1992; DeVries and Stein 1992; Welker et al. 1994; this study). On day 14 , we added bluegills at fairly high densities of 15 bluegills $/ \mathrm{m}^{3}$ (peak field densities rarely exceed 5 bluegills $/ \mathrm{m}^{3}$ in Ohio; see Figure 1). Despite low initial (24-h) handling mortality, we chose these high bluegill densities because we were concerned that small bluegills might suffer high mortality during the entire experiment. Bags $(N=4 /$ treatment) were dismantled on day $0(\sim 12 \mathrm{~h}$ after gizzard shad were added), day 14 ( $\sim 12 \mathrm{~h}$ after bluegills were added), day 19, and day 24 (Table 1; total bags $=3$ treatments $\times 4$ replicates $\times 4$ dates $=48$ bags). Zooplankton was collected on days 0 
TABLE 1.-Design of experiments conducted at Hebron State Fish Hatchery, Ohio, including treatments with differing combinations of bluegills (BG) and gizzard shad (GS), as well as those with no fish. Experimental units were plastic bags each containing about $1 \mathrm{~m}^{3}$ water.

\begin{tabular}{|c|c|c|c|c|c|c|c|c|c|}
\hline \multirow[b]{3}{*}{ Code } & \multirow[b]{3}{*}{ Dates } & \multirow{3}{*}{$\begin{array}{c}\text { Number } \\
\text { of } \\
\text { days }\end{array}$} & \multirow{2}{*}{\multicolumn{2}{|c|}{ Treatments }} & \multirow[b]{3}{*}{$\begin{array}{l}\text { Repli- } \\
\text { cates }\end{array}$} & \multicolumn{2}{|c|}{ Bluegill } & \multicolumn{2}{|c|}{ Gizzard shad } \\
\hline & & & & & & \multirow{2}{*}{$\begin{array}{c}\text { Initial } \\
\text { density } \\
\text { (fish/ } \\
\mathrm{m}^{3} \text { ) }\end{array}$} & \multirow{2}{*}{$\begin{array}{c}\text { Initial } \\
\text { total } \\
\text { length } \\
(\mathrm{mm} \pm \mathrm{SE})\end{array}$} & \multirow{2}{*}{$\begin{array}{c}\text { Initial } \\
\text { density } \\
\left(\text { fish } / \mathrm{m}^{3}\right)\end{array}$} & \multirow{2}{*}{$\begin{array}{c}\text { Initial } \\
\text { total } \\
\text { length } \\
(\mathrm{mm} \pm \mathrm{SE})\end{array}$} \\
\hline & & & Species & $\begin{array}{l}\text { Density } \\
\left(\text { fish } / \mathrm{m}^{3}\right)\end{array}$ & & & & & \\
\hline \multicolumn{10}{|c|}{ 2-week separation experiment } \\
\hline SEP & 8 June-3 July 1992 & 25 & BG only & 15 & 4 & 15 & $8 \pm 2$ & 0 & \\
\hline & & & $\mathrm{BG}+\mathrm{GS}$ & 35 & 4 & 15 & $8 \pm 1.2$ & 20 & $19 \pm 4$ \\
\hline & & & GS only & 20 & 4 & 0 & & 20 & $19 \pm 4$ \\
\hline \multicolumn{10}{|c|}{ Simultaneous, low density experiment } \\
\hline SIM & 17-29 June 1994 & 13 & BG only & 5 & 4 & 5 & $10 \pm 0.8$ & 0 & \\
\hline & & & $\mathrm{BG}+\mathrm{GS}$ & 10 & 4 & 5 & $9 \pm 0.6$ & 5 & $16 \pm 0.6$ \\
\hline & & & GS only & 5 & 4 & 0 & & 5 & $17 \pm 0.6$ \\
\hline & & & No fish & 0 & 4 & 0 & & 0 & \\
\hline \multicolumn{10}{|c|}{ Simultaneous, varying density experiment } \\
\hline SIMVARY & 20 June-5 July 1995 & 16 & BG only & 5 & 3 & 5 & $7 \pm 0.2$ & 0 & \\
\hline & & & $\mathrm{BG}+\mathrm{GS}$ & $10,15,25$ & 3 & 5 & $6 \pm 0.2$ & $5,10,20$ & $18 \pm 0.6$ \\
\hline & & & GS only & $5,10,20$ & 3 & 0 & & $5,10,20$ & $20 \pm 0.8$ \\
\hline & & & No fish & 0 & 3 & 0 & & 0 & \\
\hline
\end{tabular}

and 3 , and then every other day after bluegills were added.

Both gizzard shad and bluegills can occur in the limnetic zone simultaneously (see Figure 1). To explore how simultaneous appearance of gizzard shad and bluegills influences their growth and survival, we conducted an experiment with 5 gizzard $\mathrm{shad} / \mathrm{m}^{3}$ and 5 bluegills $/ \mathrm{m}^{3}$ added to bags simultaneously during June 1994 (SIM experiment; Table 1; duration, $13 \mathrm{~d}$ ). High survival of bluegills in 1992 (see Results, Separate Appearance) convinced us that the use of low bluegill densities was feasible. With the exception of an additional three fishless bags, overall treatments $(N=4$ replicates/ treatment) were as in 1992 (Table 1). On days 0, 5 , and 12, we sampled zooplankton and dismantled bags with fish (total bags $=3$ treatments $\times 4$ replicates $\times 3$ dates +3 fishless bags $=39$ bags $)$.

In the SIM experiment, gizzard shad densities were low relative to those that often occur in the field. To better understand how different densities of gizzard shad influence growth and survival of bluegills during their simultaneous appearance in the limnetic zone, we conducted an experiment in which bluegill densities were held constant (5 bluegills $/ \mathrm{m}^{3}$ ) while gizzard shad densities varied $\left(0,5,10,20\right.$ gizzard shad $\left./ \mathrm{m}^{3}\right)$ during June through July 1995 (SIMVARY experiment; Table 1; duration, $16 \mathrm{~d})$. Treatments $(N=8)$ were all possible combinations of bluegills (present-absent) combined with all densities of gizzard shad on day 0 . In addition, we included three fishless bags that were not dismantled through time. Zooplankton was sampled and bags with fish were dismantled on days 0,9 , and $15(N=3$ replicates/treatment; total bags $=7$ treatments $\times 3$ replicates $\times 3$ dates +3 fishless bags $=66$ bags $)$.

Analyses.-All statistical analyses were conducted with SAS (SAS Institute 1985). During all experiments, we only quantified zooplankton through time in bags that were dismantled on the last experimental day. Thus, effects of treatments on zooplankton densities were analyzed with repeated measures analysis of variance (ANOVA). All repeated measures ANOVAs included a within-subjects time effect ( $N=3$ tests). In the SEP experiment, the repeated measures ANOVA had one main effect (fish composition) with three levels: bluegills, bluegills plus shad, and shad. We only analyzed zooplankton after bluegills were added to bags on day 14. The SIM experiment repeated measures ANOVA had two main effects (bluegills; gizzard shad), each with two levels (presence or absence). The SIMVARY experiment repeated measures ANOVA included two main effects: bluegill presence (i.e., present or absent) and gizzard shad density (i.e., 0-20 gizzard $\mathrm{shad} / \mathrm{m}^{3}$ ). Data were $\log _{e}$-transformed to reduce heteroscedasticity and meet assumptions of normality. One fishless bag was lost on the final day of the SIMVARY experiment; hence, only the two remaining fishless replicates were used for that date.

Differences in wet weights of bluegills and gizzard shad among experimental treatments, as well 
as proportion surviving, were analyzed with univariate ANOVAs in which time was always a main effect ( $N=12$ tests). These responses were averaged across individuals within each bag, generating one mean for each replicate. In the SEP and SIM experiments, the main effect for bluegill growth and survival was presence of gizzard shad; conversely, the main effect for gizzard shad growth and survival was bluegill presence. In the SEP experiment, we only analyzed growth and survival of gizzard shad and bluegills after bluegills were added on day 14. In the SIMVARY experiment, the main effect for bluegill growth and survival was gizzard shad density; whereas, for gizzard shad growth and survival, the two main effects were gizzard shad density and presence or absence of bluegills. Proportions were arcsinesquare-root transformed before analyses. Growth data were $\log _{e}$-transformed to reduce heteroscedasticity and meet assumptions of normality. When applicable, we conducted Tukey's multiplecomparison tests to compare treatment means within significant main effects. One bag (bluegillplus-shad treatment) was lost by the final day of the SEP experiment. For an unknown reason, holes developed in several treatment bags on the final days of the SIMVARY experiment (treatments: two $10 \mathrm{shad} / \mathrm{m}^{3}$ only; all $20 \mathrm{shad} / \mathrm{m}^{3}$ only; one bluegill with $20 \mathrm{shad} / \mathrm{m}^{3}$; and one fishless bag); these replicates were not included in analyses.

To relate zooplankton density and bluegill growth to total biomass of gizzard shad through time ( $g$ wet weight), we calculated average biomass of gizzard shad within each replicate by the final day of each experiment, assuming that growth and mortality rates are exponential and constant throughout each experiment (Ricker 1975):

$$
\bar{B}=\frac{B_{0}\left(e^{G-z}-1\right)}{G-Z},
$$

where $B_{0}$ is the initial biomass of all individuals within a replicate bag (from average total biomass/ bag quantified on day 0$), G$ is the mean instantaneous growth rate, and $Z$ is the mean instantaneous mortality rate (Ricker 1975). We calculated instantaneous growth rates (over each experiment) as

$$
G=\log _{e}\left(\frac{W_{f}}{W_{0}}\right),
$$

in which $W_{f}$ is the average final weight in each bag and $W_{0}$ is the initial average weight for all fish at day 0 . Instantaneous mortality (again, over each experiment) was calculated as

$$
Z=-\log _{e}\left(\frac{N_{f}}{N_{0}}\right),
$$

in which $N_{f}$ and $N_{0}$ are the number of bluegills or gizzard shad in each bag on the final day and day 0 of each experiment, respectively. We compared average biomass of gizzard shad to final zooplankton density within bags using a two-dimensional Kolmogorov-Smirnov (2DKS) test (Press et al. 1992; Garvey et al. 1998b). To compare the magnitude of bluegill growth among experiments, we regressed gizzard shad total growth against bluegill growth rates $\left(\mathrm{g} \cdot \mathrm{g}^{-1} \cdot \mathrm{d}^{-1}\right)$ calculated for bags on the final day of experiments.

\section{Results}

\section{Reservoir Sampling}

Excluding Clark Lake and Stonelick Lake in 1987 when threadfin shad and gizzard shad were absent, bluegills first appeared in ichthyoplankton tows at the same time or after shad reached peak densities (median peak shad density $=22.5$ gizzard $\mathrm{shad} / \mathrm{m}^{3}$ ) in only $24 \%$ of the reservoirs and years combined (Figure 1). Among reservoirs and years, dates of first bluegill appearance (median bluegill density $=0.008$ bluegills $/ \mathrm{m}^{3}$ ) in the limnetic zone varied considerably, ranging from May 3 to June 18. Threadfin shad and gizzard shad peaked at different times. In 1988 and 1989 after threadfin shad adults were stocked and their larvae were abundant in Clark Lake and Stonelick Lake, larval shad densities generally peaked in late summer, on the same date or after bluegill densities peaked (Figure 1). Conversely, gizzard shad densities peaked between May 15 and June 19 across years and reservoirs, generally before bluegill densities peaked (Figure 1). No bluegills were captured in ichthyoplankton tows in Clark Lake in 1993. In summary, peak densities of bluegills (median density $=0.21$ bluegills $/ \mathrm{m}^{3}$ ) occurred on or after dates of peak shad densities during $71 \%$ of the reservoirs and years combined (median number of days between peaks $=25$; Figure 1 ), suggesting that temporal overlap and thus the potential for competition among these fishes was great.

Relative appearance of threadfin shad, gizzard shad, and bluegills may have influenced zooplankton availability. With the exception of 1988 and 1989 (when gizzard shad were rare or absent), zooplankton densities were low ( $<100$ zooplankters/ L) when bluegills appeared and reached peak den- 


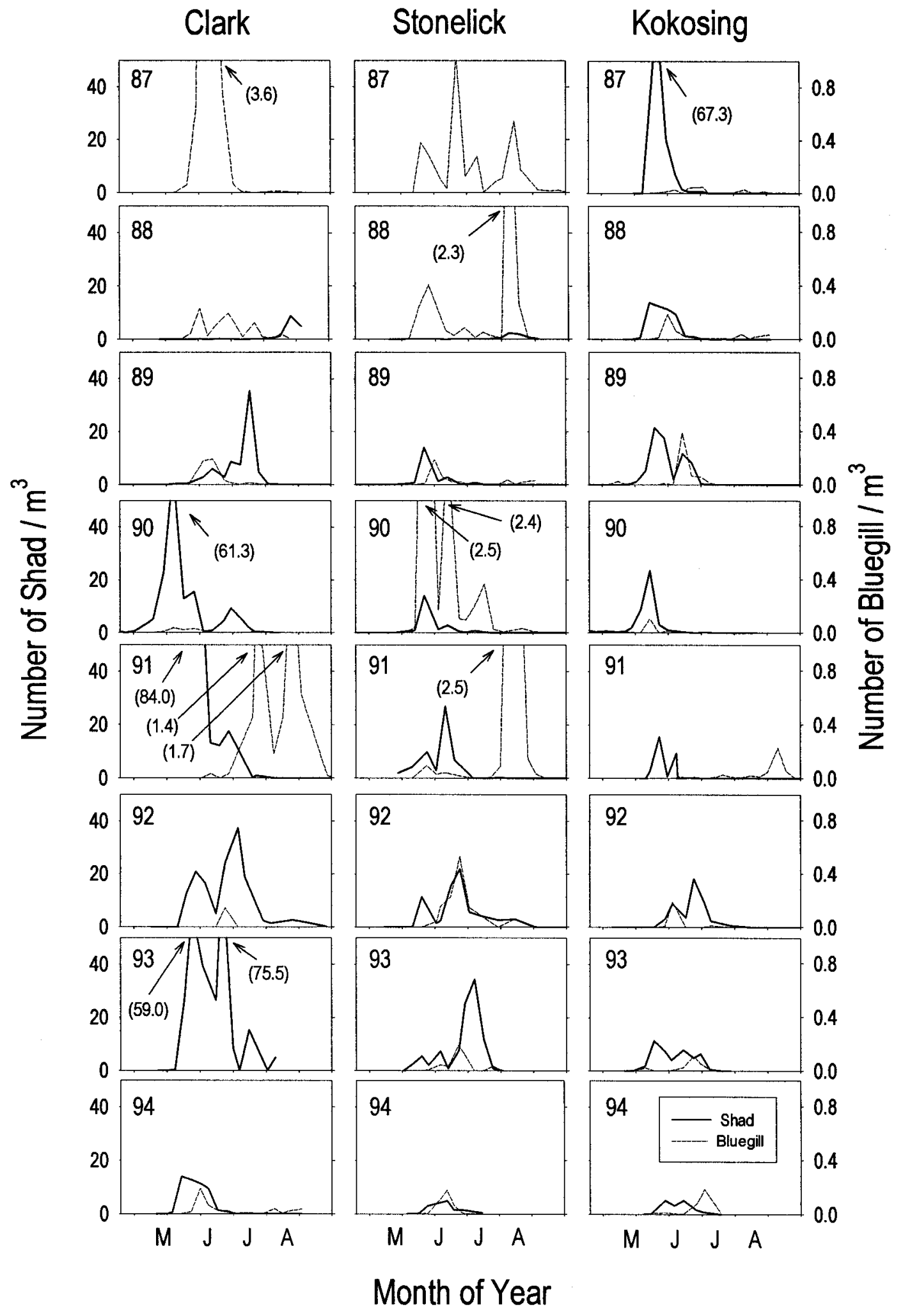


sities in Kokosing Lake (Figure 2). During 19871990 in Clark Lake and Stonelick Lake, zooplankton density was high, often exceeding 400 zooplankters/L when bluegills appeared and reached peak densities (Figure 2). Conversely, after gizzard shad became the sole shad species in these two reservoirs by 1990 , zooplankton abundance was consistently low on dates that bluegills first appeared and reached peak densities (Figure 2). By 1992, zooplankton densities in Clark Lake and Stonelick Lake had declined to the level in Kokosing Lake on these dates (consistently $<100$ zooplankters/L; Figure 2).

\section{Separate Appearance}

In the SEP experiment in which bluegills were added 2 weeks after gizzard shad, a significant fish effect, as well as an interaction between fish and time, indicated that zooplankton densities in treatments with gizzard shad declined and remained low relative to those with bluegill only (Figure 3A; Table 2). Survival of bluegills in bags was variable through time (mean survival \pm SE by last day, 72 $\pm 8 \%)$ and unrelated to the presence of gizzard shad (Table 2; two-factor ANOVA: shad, NS). For gizzard shad, a significant time effect suggested that their survival declined through time, from 81 $\pm 4 \%$ on day 14 to $32 \pm 6 \%$ by the end of the experiments (Table 2). For bluegill growth, we detected a significant shad effect, indicating that bluegills grew where gizzard shad were absent but not where gizzard shad had been present for 2 weeks (Figure 3B; Table 2; two-factor ANOVA: shad, $P<0.05)$. Gizzard shad growth was unaffected by bluegills (Figure 3C; Table 2; two-factor ANOVA: bluegill, NS).

\section{Simultaneous Appearance}

In the SIM experiment in which initial densities of both gizzard shad and bluegills added simultaneously were low, densities of zooplankton were consistently lower through time in treatments with gizzard shad than in treatments with bluegills or without fish (Figure 4A; Table 3; repeated measures ANOVA: shad, $P<0.05)$, though densities of zooplankton were generally low for all treatments ( $<150$ zooplankters/L). Though we detected an effect of time on survival of bluegills (Table $3)$, survival increased from day $0(73 \pm 0.3 \%)$ to the last day $(95 \pm 4 \%)$, indicating that we may have failed to recover all surviving bluegills during the dismantling of bags on day 0. Gizzard shad survival was high $(83 \pm 6 \%$ by the last day) and unaffected by bluegills and time (Table 3; twofactor ANOVA: time, NS; bluegill, NS). Bluegills grew through time (Figure 4B; Table 3; two-factor ANOVA: time, $P<0.05)$. Gizzard shad did not affect bluegill growth (Figure 4B; Table 3; twofactor ANOVA: shad, NS). Conversely, gizzard shad growth was reduced by bluegills (Figure 4C; Table 3; bluegill, $P<0.05)$.

In the SIMVARY experiment in which we added bluegills to bags with gizzard shad of varying densities, only a significant shad effect and shad $\times$ time interaction occurred because zooplankton fell to lower densities in treatments with gizzard shad than in treatments with bluegill and with fishless bags (Figure 5A; Table 4). For both bluegills and gizzard shad, survival through time was unrelated to treatment (Table 4). By the end of the experiment, $93 \pm 3 \%$ bluegills and $92 \pm 4 \%$ gizzard shad survived. Though bluegills grew through time (Figure 5B; Table 4; two-factor ANOVA: time, $P$ $<0.05$ ), gizzard shad influenced the extent of bluegill growth (Table 4; two-factor ANOVA: shad, $P$ $<0.05)$. A posthoc comparison demonstrated that growth of bluegills in bluegill-only treatments exceeded that in 10 and 20 gizzard $\mathrm{shad} / \mathrm{m}^{3}$ treatments (Figure 5B; Tukey's test, $P<0.05$ ). No other pairwise comparisons were significant for bluegill growth (Figure 5B; Tukey's test, NS). A significant time effect occurred because gizzard shad grew through time (Figure 5C; Table 4). Even so, gizzard shad density influenced gizzard shad growth (Figure 5C; Table 4; three-factor ANOVA: shad, $P<0.05$ ), with growth of gizzard shad declining as their density increased (Tukey's test, $P$ $<0.05)$. Bluegills did not influence gizzard shad growth (Figure 5C; Table 4; three-factor ANOVA: bluegill, NS). A significant interaction among

$\leftarrow$

FIGURE 1.-Mean densities (number/m³ $\mathrm{m}^{3} N=2$ tows per date and reservoir) of larval bluegills (broken lines) and threadfin shad and gizzard shad (pooled as shad; solid lines) in the limnetic zones of Clark, Stonelick, and Kokosing reservoirs, Ohio, during 1987-1994. Densities exceeding scales on panels are in parentheses. In 1988 and 1989 in Clark and Stonelick reservoirs, threadfin shad adults were stocked, and thus, threadfin shad was the most abundant shad species in ichthyoplankton tows. During all other years in all reservoirs, gizzard shad was the sole shad species present. In 1993, no bluegills were captured in ichthyoplankton tows in Clark Lake. 


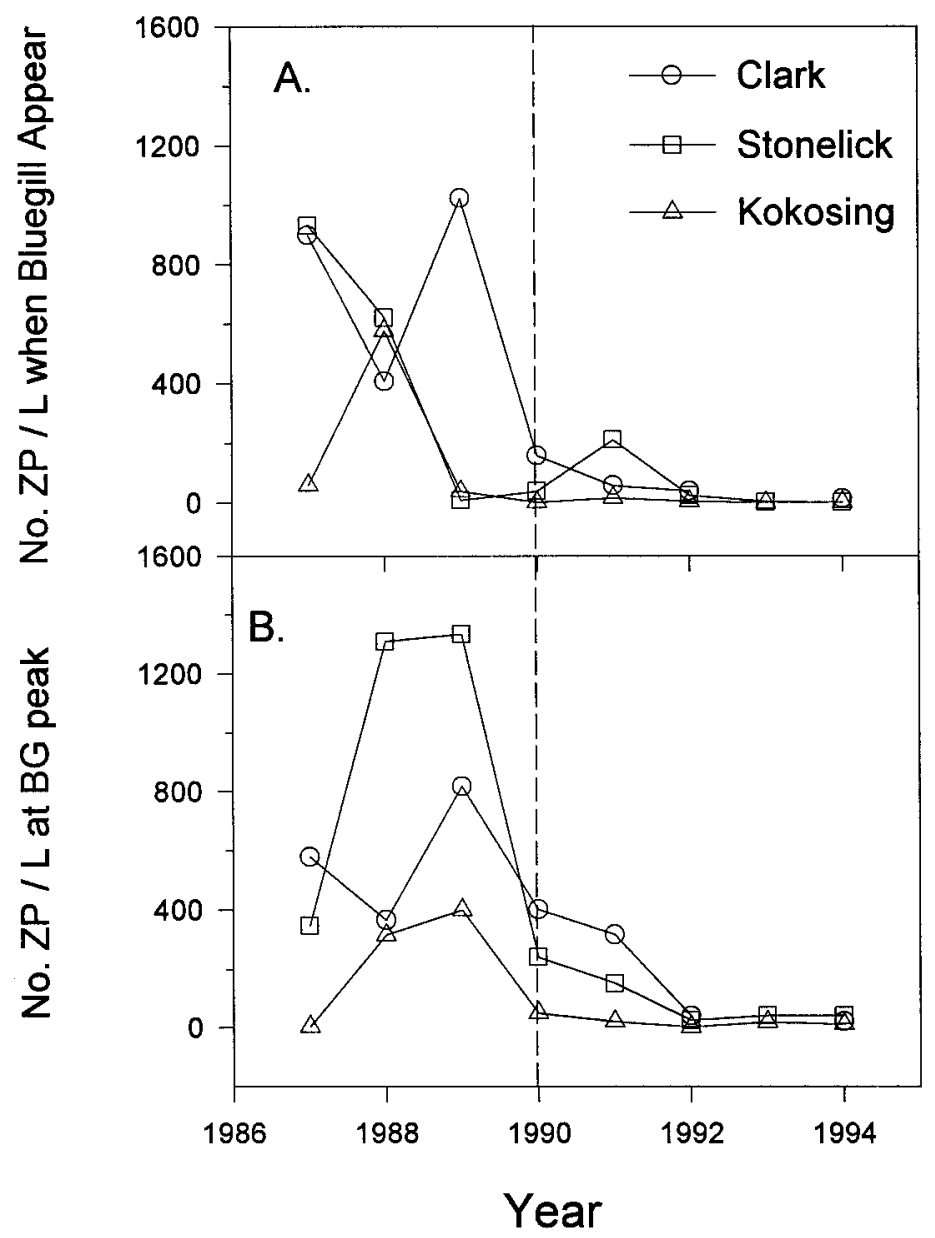

FiguRE 2.-Mean crustacean zooplankton (ZP)/L ( $N=3-5$ sites per reservoir and date) on dates (A) when bluegills (BG) first appeared and (B) when bluegills reached peak densities in ichthyoplankton tows in Clark Lake, Stonelick Lake, and Kokosing Lake, Ohio, during 1987-1994. Gizzard shad were always present in Kokosing Lake. Threadfin shad and gizzard shad were added to Stonelick Lake and Clark Lake in 1988; by 1990 (denoted by broken vertical line), gizzard shad was the only shad species present in all three reservoirs.

time, bluegill, and gizzard shad effects may have occurred as combined bluegill and gizzard shad biomass reduced gizzard shad growth during the latter part of the experiment (Figure 5C; Table 4).

\section{General Experimental Patterns}

Water temperatures averaged 24, 27.7, and $27.7^{\circ} \mathrm{C}$ during the SEP, SIM, and SIMVARY experiments, respectively, with temperatures generally fluctuating $\pm 3^{\circ} \mathrm{C}$ daily. Zooplankton taxa in bags generally were dominated by Bosmina, calanoid copepods, nauplii, and ostracods, and there were no apparent differences across treatments and experiments. Taxa in diets of bluegills and gizzard shad overlapped during all experiments, with fish generally consuming Bosmina, Chydorus, cyclopoid copepods, and ostracods; mean lengths of zooplankton consumed by fishes overlapped as well, ranging from 0.2 to $0.8 \mathrm{~mm}$. Though zooplankton often were abundant in diets, bluegills and gizzard shad also consumed chironomid larvae that were present on bag sides during each experiment. To determine if fish were consuming chironomids as zooplankton declined, we compared zooplankton density to mean proportion of chironomid biomass (relative to zooplankton; mg dry weight) in diets of gizzard shad and bluegills on the last day of experiments within each bag. The proportion of chironomids in diets should increase with declining zooplankton if they were important 


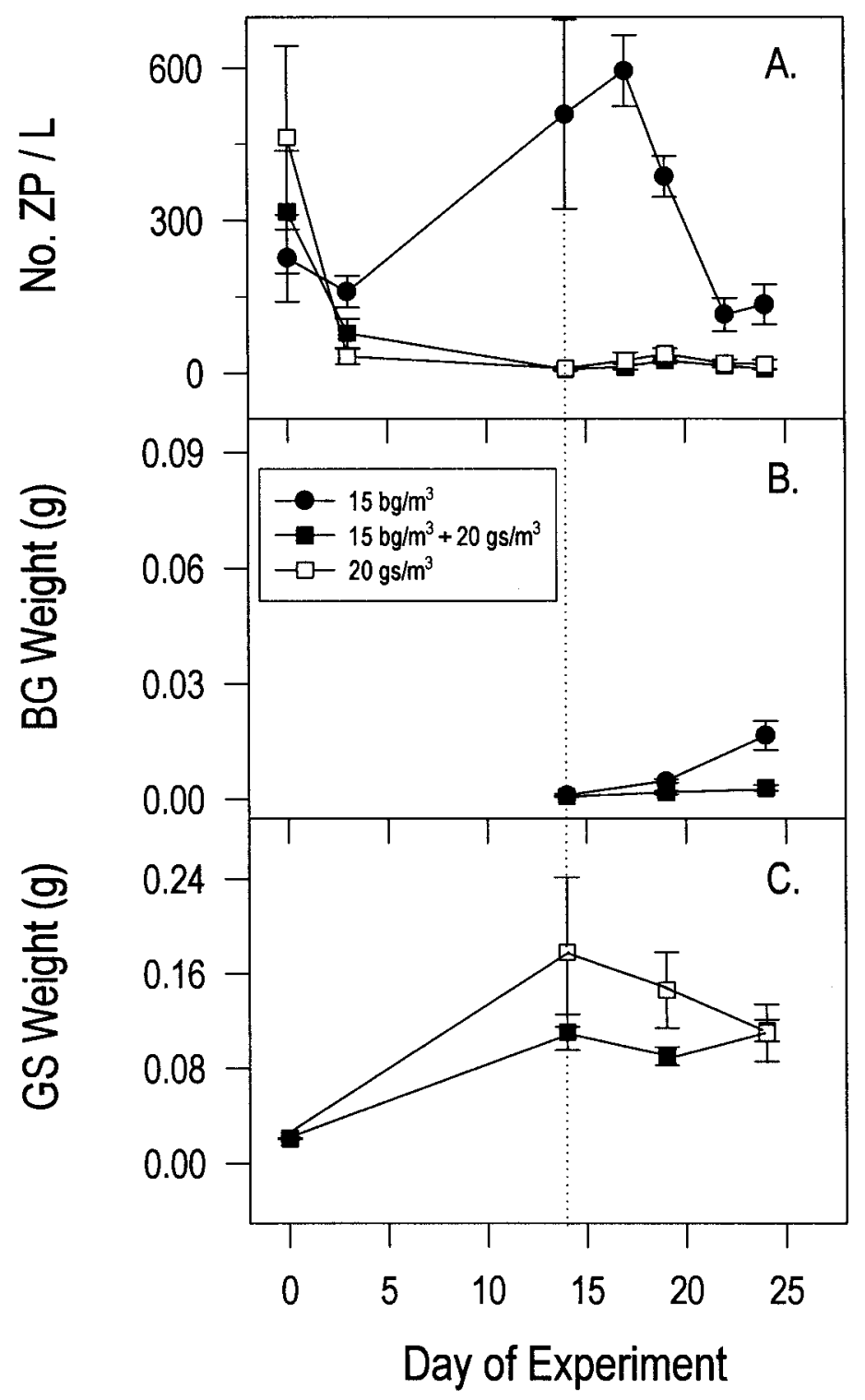

FigURE 3.- (A) Number of zooplankton (ZP)/L, (B) bluegill (BG) wet weight, and (C) gizzard shad (GS) wet weight through time during an experiment in which bluegills were added 2 weeks after gizzard shad. Values are means, and vertical bars represent $\pm \mathrm{SE}$; the dotted line indicates when bluegills were added to bags.

as alternate prey. In fact, we found that the relative abundance of chironomids in diets varied (comprising $0-100 \%$ of diet biomass of individual fish) and was unrelated to zooplankton density for both bluegills and gizzard shad $(N=26$ for both tests; 2DKS test: bluegill, $D=0.08$; shad, $D=0.09$; both tests NS), suggesting that starving fish did not consistently increase their consumption by switching to chironomid prey.

On the last day across experiments, zooplankton density declined with increasing gizzard shad average biomass (Figure 6A; 2DKS test: $D=0.17$, $P<0.05)$. This relationship appeared driven by high zooplankton densities without gizzard shad at the end of the SEP experiment. Bluegill growth rates were similar among experiments when gizzard shad were absent (Figure 6B). As with the ANOVA, our regression detected declining bluegill growth rates with increasing gizzard shad average biomass in the SEP experiment (Figure 6B; 
TABLE 2.-Results of repeated-measures analysis of variance (ANOVA) for changes in zooplankton density (number/ $\mathrm{L}$ ) and two-factor univariate ANOVAs for survival (proportion surviving) and growth ( $\mathrm{g}$ wet weight) of bluegills and gizzard shad through time (days 14-24) during the SEP experiment conducted at Hebron State Fish Hatchery, JuneJuly 1992. Proportion of bluegills and gizzard shad surviving in each experimental bag was arcsine-square-root-transformed before analysis. All other responses were $\log _{e}$ transformed. For the repeated-measures ANOVA, levels of the fish effect were bluegill only, bluegills plus gizzard shad, and gizzard shad only. For the univariate ANOVAs, levels within both shad and bluegill effects were presence-absence. See Figure $3 \mathrm{~A}-\mathrm{C}$ for corresponding data. Asterisks indicate significance at $P<0.05^{*} ; P<0.01 * * ; P<0.001 * * * ; P<0.0001 * * * *$.

\begin{tabular}{|c|c|c|c|c|}
\hline $\begin{array}{c}\text { Response } \\
\text { variable }\end{array}$ & Effect & df & $F$ & $P$ \\
\hline \multirow[t]{3}{*}{ Zooplankton } & Fish & 2,8 & 39.0 & $* * * *$ \\
\hline & Time & 3,24 & 5.8 & $* *$ \\
\hline & Fish $\times$ time & 6,24 & 3.4 & $*$ \\
\hline \multicolumn{5}{|l|}{ Survival } \\
\hline \multirow[t]{3}{*}{ Bluegill } & Shad & 1,22 & 1.1 & 0.3 \\
\hline & Time & 2,22 & 1.0 & 0.4 \\
\hline & Shad $\times$ time & 2,22 & 5.5 & $* *$ \\
\hline \multirow[t]{3}{*}{ Shad } & Bluegill & 1,22 & 3.3 & 0.06 \\
\hline & Time & 2,22 & 28.3 & $* * * *$ \\
\hline & Bluegill $\times$ time & 2,22 & 0.9 & 0.4 \\
\hline \multicolumn{5}{|l|}{ Growth } \\
\hline \multirow[t]{3}{*}{ Bluegill } & Shad & 1,22 & 37.3 & $* * * *$ \\
\hline & Time & 2,22 & 27.1 & $* * * *$ \\
\hline & Shad $\times$ time & 2,22 & 3.5 & 0.05 \\
\hline \multirow[t]{3}{*}{ Shad } & Bluegill & 1,22 & 2.0 & 0.2 \\
\hline & Time & 2,22 & 0.6 & 0.6 \\
\hline & Bluegill $\times$ time & 2,22 & 1.1 & 0.4 \\
\hline
\end{tabular}

$F$-tests for slopes: SEP, $F=19.9$, df $=1,7, P<$ $0.05)$. Interestingly, the regression detected a negative relationship between bluegill growth and gizzard shad biomass (Figure 6B; $F$-tests for slopes: SIM, $F=7.1$, df $=1,7, P<0.05)$, though our previous ANOVA did not (see Table 3 ). Conversely, the regression detected no relationship for the SIMVARY experiment ( $F$-tests for slopes: SIMVARY, $F=1.6$, df $=1,9, \mathrm{NS})$, though the ANOVA did (see Table 4). Regardless, increasing gizzard shad biomass had a much stronger effect in the SEP experiment, causing a twofold reduction in bluegill growth rates (Figure 6B).

\section{Discussion}

Variable Larval Appearance in the Limnetic Zone

Timing of appearance and peak densities of threadfin shad and gizzard shad varied among reservoirs and years, potentially influencing the extent of competitive interactions with bluegills. Differences in reproduction between threadfin shad and gizzard shad might be partially responsible for differences in relative appearance of larvae. In Stonelick Lake and Clark Lake in 1988 and 1989, densities of threadfin shad did not peak until late summer, generally at the same time (Stonelick Lake both years) or after (Clark Lake both years) most bluegills had appeared. Like gizzard shad, adult threadfin shad generally spawn during early spring (Shelton et al. 1982; Allen and DeVries 1993). However, DeVries et al. (1991) suggest that late-summer peaks of threadfin shad poststocking in Stonelick Lake and Clark Lake derived from early maturation of age- 0 individuals during their first year plus drought that delayed adult spawning. By 1990, when gizzard shad became dominant in these two reservoirs, peaks of larval gizzard shad often occurred before or during peaks of bluegills (67\% of reservoir and years combined). Similarly, in Kokosing Lake, which always contained gizzard shad, gizzard shad peaked first or simultaneously with bluegills during all years. Despite considerable variation in the relative occurrence of peaks, the frequent late peaks of bluegills relative to gizzard shad potentially provided the $1-3$ weeks necessary for gizzard shad to deplete zooplankton and compromise bluegill growth and survival.

\section{Relative Timing and Interspecific Competition}

Our experiments suggested that relative timing of appearance of bluegills and gizzard shad influences the extent of exploitative competition for zooplankton prey. Gizzard shad reached peak densities more than 2 weeks before bluegill peaks in $43 \%$ of the reservoirs and years combined. Hence, the SEP experiment mimicked a common timing scenario in these systems. Given this timing advantage in the SEP experiment, gizzard shad 


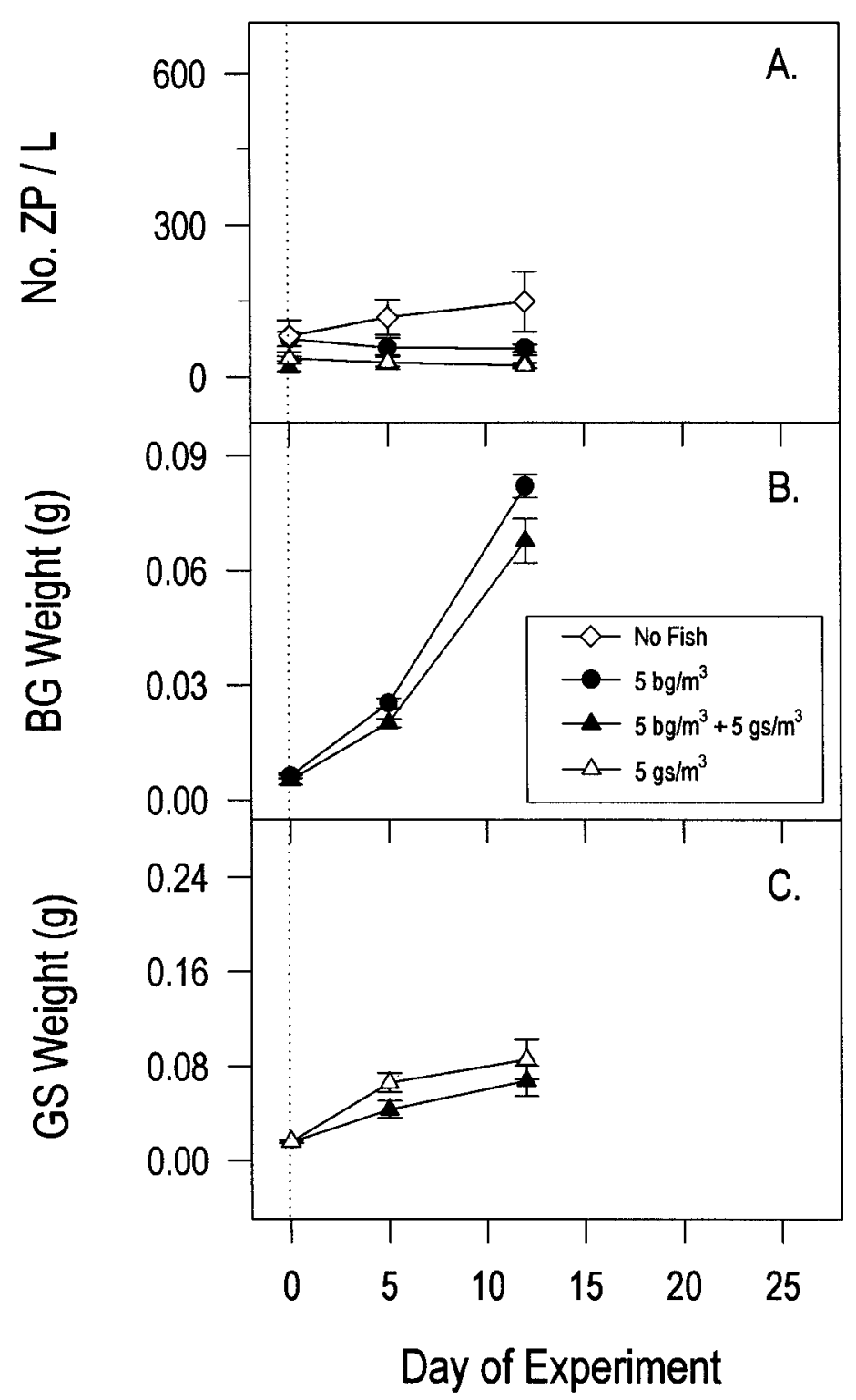

FigURE 4.-(A) Number of zooplankton (ZP)/L, (B) bluegill (BG) wet weight, and (C) gizzard shad (GS) wet weight through time during an experiment in which bluegills and gizzard shad were added simultaneously at low densities of 5 individuals $/ \mathrm{m}^{3}$. Values are means, and vertical bars represent $\pm \mathrm{SE}$; the dotted line indicates when bluegills were added to bags.

quickly depleted (and continued to suppress) zooplankton densities through the experiment. Similarly, in mesocosms in three Ohio reservoirs with differing zooplankton productivities, gizzard shad at densities and sizes $\left(\sim 10\right.$ individuals $/ \mathrm{m}^{3}$ at 23 $\mathrm{mm}$ TL) similar to our experiment often reduced zooplankton within 2 weeks (Dettmers and Stein 1996). In the view of Dettmers and Stein (1996), zooplankton depletion by juvenile gizzard shad ap- pears common, compromising growth and survival of co-occurring sportfish when zooplankton densities fall below 100 zooplankters/L (as per Werner and Blaxter 1980; Eldridge et al. 1981; Li and Mathias 1982). As they predicted, when zooplankton densities were less than 100 individuals/L and bluegills were added to our bags with gizzard shad, their growth declined, supporting our interpretation that interspecific competition for limited zoo- 
TABLE 3.-Results of repeated-measures analysis of variance (ANOVA) for changes in zooplankton density (number/ L) and two-factor univariate ANOVAs for survival (proportion surviving) and growth ( $\mathrm{g}$ wet weight) of bluegills and gizzard shad through time (days 0-12) during the SIM experiment conducted at Hebron State Fish Hatchery, June 1994. Proportion of bluegills and gizzard shad surviving in each experimental bag was arcsine-square-root-transformed before analysis. All other responses were $\log _{e}$ transformed. For all tests, levels of both bluegill and shad effects were presenceabsence. See Figure 4A-C for corresponding data. Asterisks indicate significance at $P<0.05^{*} ;<0.01 * * ; P<0.001 * * *$; $P<0.0001^{* * * * *}$.

\begin{tabular}{|c|c|c|c|c|}
\hline $\begin{array}{l}\text { Response } \\
\text { variable }\end{array}$ & Effect & df & $F$ & $P$ \\
\hline \multirow[t]{7}{*}{ Zooplankton } & Bluegill & 1,11 & 0.6 & 0.4 \\
\hline & Shad & 1,11 & 12.0 & $* *$ \\
\hline & Bluegill $\times$ shad & 1,11 & 0.2 & 0.7 \\
\hline & Time & 2,22 & 0.0 & 1.0 \\
\hline & Time $\times$ bluegill & 2,22 & 0.1 & 0.9 \\
\hline & Time $\times$ shad & 2,22 & 0.2 & 0.8 \\
\hline & Time $\times$ bluegill $\times$ shad & 2,22 & 3.9 & $*$ \\
\hline \multicolumn{5}{|l|}{ Survival } \\
\hline \multirow[t]{3}{*}{ Bluegill } & Shad & 1,23 & 3.5 & 0.08 \\
\hline & Time & 2,23 & 10.7 & $* * *$ \\
\hline & Shad $\times$ time & 2,23 & 3.5 & 0.05 \\
\hline \multirow[t]{3}{*}{ Shad } & Bluegill & 1,23 & 0.4 & 0.5 \\
\hline & Time & 2,23 & 0.9 & 0.4 \\
\hline & Bluegill $\times$ time & 2,23 & 0.1 & 0.9 \\
\hline \multicolumn{5}{|l|}{ Growth } \\
\hline \multirow[t]{3}{*}{ Bluegill } & Shad & 1,23 & 3.4 & 0.08 \\
\hline & Time & 2,23 & 173.0 & $* * * *$ \\
\hline & Shad $\times$ time & 2,23 & 0.3 & 0.8 \\
\hline \multirow[t]{3}{*}{ Shad } & Bluegill & 1,23 & 5.7 & $*$ \\
\hline & Time & 2,23 & 44.0 & $* * * *$ \\
\hline & Bluegill $\times$ time & 2,23 & 1.2 & 0.3 \\
\hline
\end{tabular}

plankton compromises bluegill success in reservoirs.

Although interspecific competitive interactions were apparently asymmetric in favor of gizzard shad that were given a timing advantage in our SEP experiment, gizzard shad also grew poorly during days 14-25, suffering high mortality. Larval gizzard shad do not tolerate starvation well (Kashuba and Matthews 1984; Matthews 1984; Welker et al. 1994), often succumbing to food limitation. Though intraspecific competition influenced gizzard shad success, our bags did not contain sediment, preventing gizzard shad from switching to detritus (Mundahl and Wissing 1988; Mundahl 1991) and increasing deleterious effects of zooplankton depletion. In partial contrast to gizzard shad, bluegills grew poorly but suffered little mortality. Though bluegills apparently are more resistant to starvation (this study; Welker et al. 1994), reduced growth and small size should increase their vulnerability to predators in reservoirs, especially as they move to the littoral zone and encounter their primary predator, largemouth bass Micropterus salmoides (Timmons et al. 1980; Keast and Eadie 1985; Bettoli et al. 1992; Olson 1996; Garvey and Stein 1998).

When strong temporal and spatial overlap oc- curs, increasing fish density and, hence, total biomass should elicit density-dependent reductions in growth, regardless of species composition (Welker et al. 1994). For all experiments, both individual size and total biomass of gizzard shad initially was much greater than that of bluegills across treatments, as our field survey demonstrated is common for Ohio reservoirs. When gizzard shad and bluegills were added to bags simultaneously, zooplankton densities declined more in bags with gizzard shad than in bags with only bluegills, which was probably a function of the gizzard shads' greater biomass. Surprisingly, depletion of zooplankton by gizzard shad only slightly reduced growth of bluegill larvae in the SIM and SIMVARY experiments. In a similar experiment, Welker et al. (1994) explored competitive interactions between larval gizzard shad and bluegills added simultaneously in microcosms. As in our experiments, they found that total fish density rather than greater species-specific consumption by gizzard shad was responsible for reduced larval growth. Apparently, gizzard shad do not have faster individual consumption rates relative to other larvae. Thus, if other larval fishes appear early enough to consume zooplankton before it is eliminated by abundant gizzard shad, these larvae may consume zooplank- 


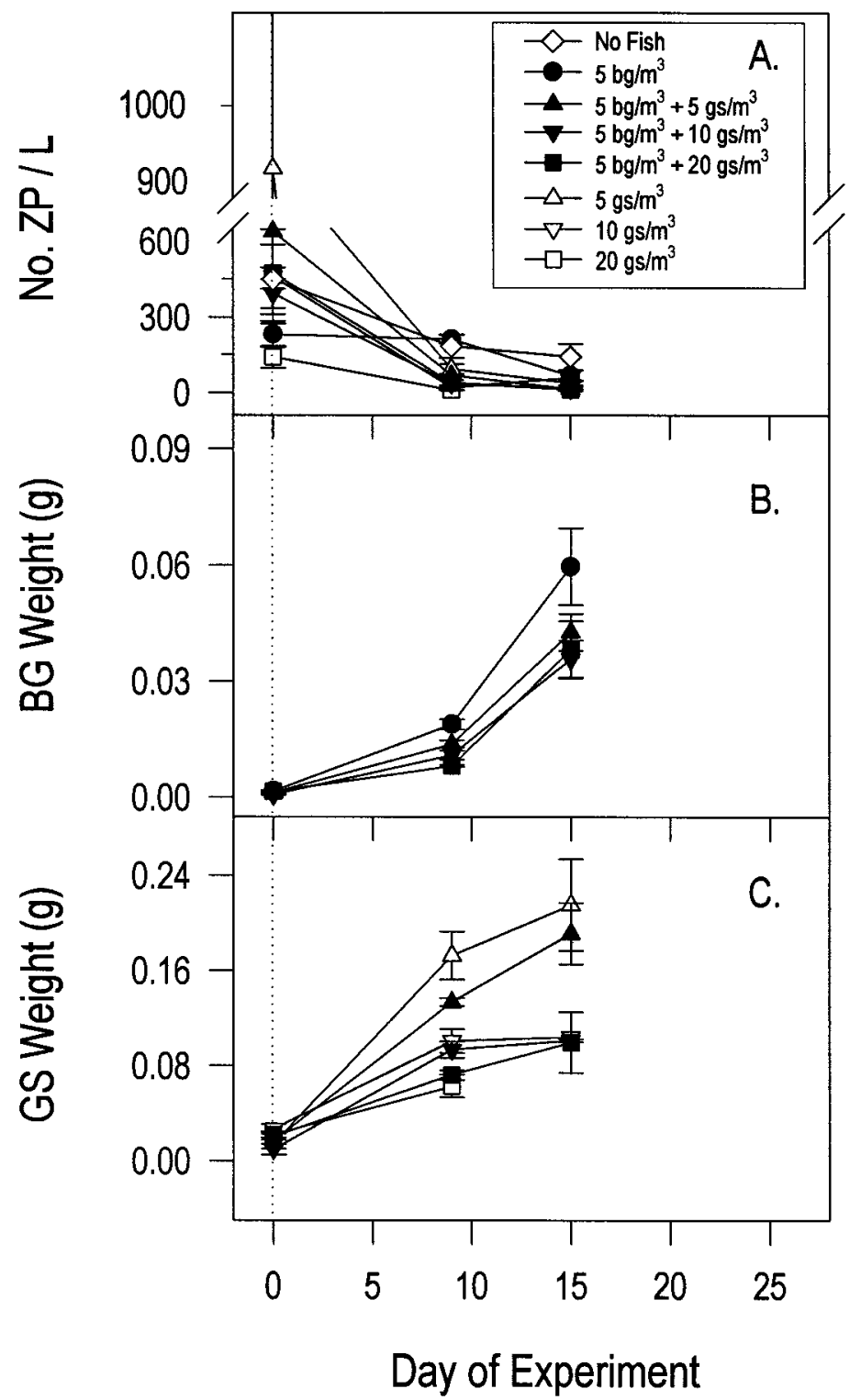

Figure 5.- (A) Number of zooplankton (ZP)/L, (B) bluegill (BG) wet weight, and (C) gizzard shad (GS) wet weight through time during an experiment in which bluegills at one density $\left(5 / \mathrm{m}^{3}\right)$ were stocked with varying densities of gizzard shad. Values are means, and vertical bars represent $\pm \mathrm{SE}$; the dotted line indicates when bluegills were added to bags.

ton and grow before it is completely incorporated into the total fish biomass. To confirm this conclusion, when larval gizzard shad and larval white crappies Pomoxis annularis appeared simultaneously and at similar densities in Alabama ponds, gizzard shad had no negative interspecific effect, probably because zooplankton was equally available to all larvae at the outset (Pope and DeVries 1994).
Relative to densities of gizzard shad and threadfin shad in reservoirs, larval bluegill densities were low during all years. Hence, bluegill-driven, density-dependent reductions in zooplankton and therefore larval growth should be uncommon. However, for unknown reasons, bluegills slightly reduced growth of gizzard shad during the SIM experiment. Probably, exploitative competition by bluegills did not cause this negative interaction, 
TABLE 4.- Results of repeated-measures analysis of variance (ANOVA) for changes in zooplankton density (number/ L) and two-factor or three-factor univariate ANOVAs for survival (proportion surviving) and growth ( $\mathrm{g}$ wet weight) of bluegills and gizzard shad through time (days 0-15) during the SIMVARY experiment conducted at Hebron State Fish Hatchery, June-July 1995. Proportion of bluegills and gizzard shad surviving in each experimental bag was arcsinesquare-root-transformed before analysis. All other responses were $\log _{e}$ transformed. For all tests, levels of bluegill effect were presence-absence; shad effect levels were 0, 5, 10, 20 gizzard shad $/ \mathrm{m}^{3}$. See Figure 5A-C for corresponding data. Asterisks denote significance at $P<0.05^{*} ; P<0.01 * * ; P<0.001 * * * ; P<0.0001 * * * *$.

\begin{tabular}{|c|c|c|c|c|}
\hline $\begin{array}{c}\text { Response } \\
\text { variable }\end{array}$ & Effect & df & $F$ & $P$ \\
\hline \multirow[t]{7}{*}{ Zooplankton } & Bluegill & 1,10 & 4.0 & 0.1 \\
\hline & Shad & 3,10 & 5.3 & $*$ \\
\hline & Bluegill $\times$ shad & 2,10 & 0.0 & 1.0 \\
\hline & Time & 2,22 & 41.7 & $* * * *$ \\
\hline & Time $\times$ bluegill & 2,22 & 2.4 & 0.1 \\
\hline & Time $\times$ shad & 6,22 & 3.4 & $*$ \\
\hline & Time $\times$ bluegill $\times$ shad & 4,22 & 0.7 & 0.6 \\
\hline \multicolumn{5}{|l|}{ Survival } \\
\hline \multirow[t]{3}{*}{ Bluegill } & Shad & 3,34 & 1.1 & 0.4 \\
\hline & Time & 2,34 & 1.1 & 0.4 \\
\hline & Shad $\times$ time & 6,34 & 0.6 & 0.8 \\
\hline \multirow[t]{7}{*}{ Shad } & Bluegill & 1,46 & 1.0 & 0.3 \\
\hline & Gizzard shad & 2,46 & 1.2 & 0.3 \\
\hline & Bluegill $\times$ shad & 2,46 & 1.0 & 0.4 \\
\hline & Time & 2,46 & 0.6 & 0.6 \\
\hline & Time $\times$ bluegill & 2,46 & 1.1 & 0.4 \\
\hline & Time $\times$ shad & 4,46 & 2.5 & 0.06 \\
\hline & Time $\times$ bluegill $\times$ shad & 3,46 & 0.0 & 1.0 \\
\hline \multicolumn{5}{|l|}{ Growth } \\
\hline \multirow[t]{3}{*}{ Bluegill } & Shad & 3,34 & 8.3 & $* * *$ \\
\hline & Time & 2,34 & 490.0 & $* * * *$ \\
\hline & Shad $\times$ time & 6,34 & 2.0 & 0.1 \\
\hline \multirow[t]{7}{*}{ Shad } & Bluegill & 1,46 & 2.3 & 0.1 \\
\hline & Shad & 2,46 & 11.1 & $* * * *$ \\
\hline & Bluegill $\times$ shad & 2,46 & 2.8 & 0.08 \\
\hline & Time & 2,46 & 201.0 & $* * * *$ \\
\hline & Time $\times$ bluegill & 2,46 & 2.4 & 0.1 \\
\hline & Time $\times$ shad & 4,46 & 6.1 & $* * *$ \\
\hline & Time $\times$ bluegill $\times$ shad & 3,46 & 4.9 & $* *$ \\
\hline
\end{tabular}

given that they did not reduce zooplankton densities. Differences between experiments in bluegill density may have influenced patterns of bluegill growth. However, bluegills (at 5 individuals $/ \mathrm{m}^{3}$ ) in the SIM and SIMVARY experiments grew as rapidly as those without gizzard shad in the SEP experiment, in which bluegill densities were higher (at 15 individuals $/ \mathrm{m}^{3}$ ). Similar growth of bluegills across these densities suggests that 15 bluegills $/ \mathrm{m}^{3}$ were insufficient to elicit density-dependent reductions in growth.

Understanding zooplankton dynamics lends insight into growth patterns of planktivorous larval fishes (Noble 1975; Confer and Lake 1987; Duffy et al. 1996). In the SIM experiment, zooplankton densities did not decline through time, even with growing fish. Potentially, productivity of zooplankton in bags was sufficient to sustain both zooplankton and fish growth (Dettmers and Stein 1996). In the SIMVARY experiment, zooplankton densities did decline through time. With this de- cline came only moderate effects of gizzard shad on bluegills (at densities $\geq 10$ gizzard $\mathrm{shad} / \mathrm{m}^{3}$ ) and no species-specific selection for different taxa or sizes of zooplankton, suggesting that exploitative or interference competition was slight. Given these moderate effects and no survival differences, gizzard shad and bluegills that appear simultaneously and confront similar zooplankton densities in reservoirs probably will coexist. As our SIMVARY experiment documented, declining zooplankton coupled with increasing fish density will compromise growth of both species (similar to Welker et al. 1994) in systems in which this decline occurs before gizzard shad switch to detritivory and bluegills move to the littoral zone where they switch to invertebrate prey.

\section{General Patterns}

From experiments, we predict that zooplankton depletion by juvenile gizzard shad will have relatively predictable deleterious effects on bluegills 


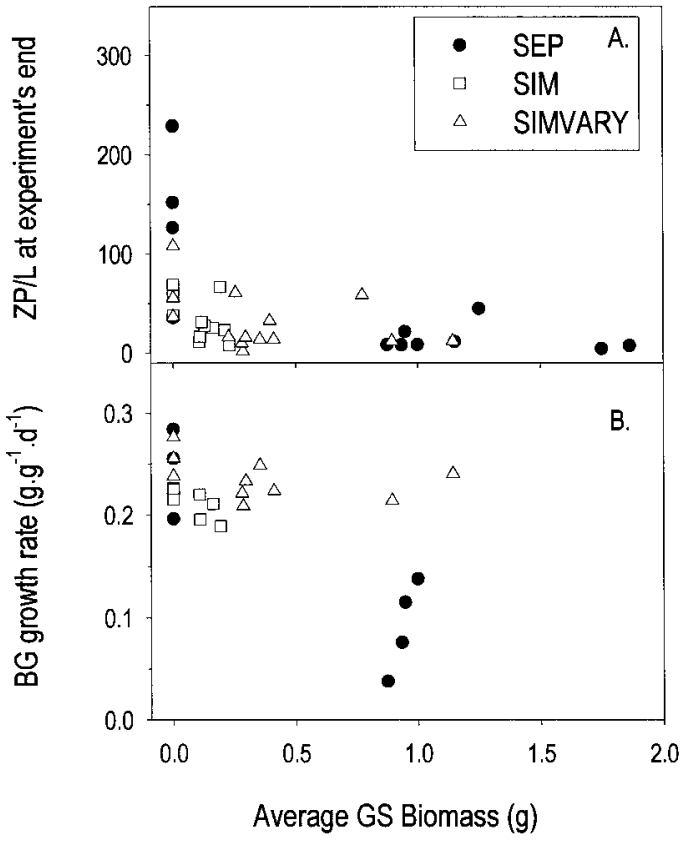

FigURE 6.-(A) Number of crustacean zooplankton $(\mathrm{ZP}) / \mathrm{L}$ in bags on the final day of experiments as a function of gizzard shad (GS) average biomass (two-dimensional Kolmogorov-Smirnov test, $P<0.05$ ). Average biomass is defined as the average gizzard shad biomass (g) within bags during each experiment, including the biomass of individuals that died. (B) Relationship between gizzard shad average biomass (which included biomass of individuals dying during the experiment) and growth rate of bluegills $\left(\mathrm{g} \cdot \mathrm{g}^{-1} \cdot \mathrm{d}^{-1}\right)$ for the three experiments where bluegills either were added 2 weeks after gizzard shad or simultaneously with varying densities of gizzard shad. At $0 \mathrm{~g}$ average biomass of gizzard shad, gizzard shad were not present in bags.

when gizzard shad appear relatively early. For the remaining years in which peak abundances of bluegills occur before or at the same time as gizzard shad, growth of bluegills and gizzard shad probably will vary with initial zooplankton density and total fish biomass in the limnetic zone. During most years, a few bluegill larvae appear early relative to shad peaks. In reservoirs, these few individuals should grow rapidly and survive well, contributing to bluegill persistence, albeit at low densities (see Pope and DeVries 1994 for a similar argument for white crappie).

Combining experiments with our field survey provides insight into patterns of bluegill abundance in Clark Lake, Stonelick Lake, and Kokosing Lake. In Kokosing Lake, recruitment of juvenile bluegills to the littoral zone was low across all years (Bremigan et al. 1991; Garvey et al. 1998a). After threadfin shad were introduced into Clark Lake and Stonelick Lake in 1988, peak littoral abundances of juvenile bluegills declined and converged on the consistently low densities in Kokosing Lake by 1990 (DeVries et al. 1991; Bremigan et al. 1991), with this pattern continuing through 1994 (Garvey et al. 1998a). During 19901994 in all reservoirs, zooplankton densities were consistently low upon bluegill appearance and peaks in the limnetic zone. In our view, these low zooplankton densities probably were caused, in part, by early appearing gizzard shad. Consequently, growth and survival of bluegills was compromised, reducing their littoral densities.

Even given a timing advantage, it has been suggested that reductions in zooplankton by juvenile gizzard shad might not influence growth and survival of larval bluegills (Welker et al. 1994). In one Illinois reservoir during 1 year, Welker et al. (1994) quantified survival of larval bluegills by comparing the distribution of first-feeding dates of littoral juveniles to larval densities in the limnetic zone. Although larval gizzard shad appeared first and zooplankton subsequently declined as limnetic larval bluegills appeared, the earliest-feeding bluegill larvae did not survive at higher rates, leading the authors to conclude that interspecific competition was not important in this system. Though their conclusion might be valid, zooplankton densities only exceeded 100 organisms/L on one date when larval bluegills occupied the limnetic zone (about 140 organisms/L). During the remaining dates of limnetic occupancy by bluegills, zooplankton densities varied around 75 organisms/L, similar to densities found in our survey of Ohio reservoirs where bluegill recruitment to the littoral zone was consistently low. In our view, relative growth and survival of larval bluegills in this Illinois reservoir should have varied little among dates of first feeding and may be generally low relative to years when gizzard shad do not reduce zooplankton. Because the authors only sampled a single system during 1 year, they were unable to characterize relative survival of bluegills as a function of variable timing of appearance and, thus, could not assess whether overall survival of larvae was "low" or "high" during their study.

In addition to early peaks of larval gizzard shad density, other factors may have reduced zooplankton densities for bluegills in Ohio reservoirs. Indeed, zooplankton for bluegills was low even during the few years when gizzard shad did not have priority appearance. Though we have no direct evidence for planktivory by age 1 or adult gizzard 
shad or other planktivores in these reservoirs, adult planktivory reduces the abundance of zooplankton in other systems (e.g., cisco Coregonus artedi in Lake Mendota, Wisconsin; Rudstam et al. 1993; Johnson and Kitchell 1996). In addition, in planktivore exclosures in Kokosing Lake and Clark Lake in spring 1992, Dettmers and Stein (1996) discovered that zooplankton abundances increase relative to the open water and hypothesized that resident planktivores were driving low zooplankton densities (also see DeVries and Stein 1992). Generally, our field pattern supports the hypothesis that planktivory by early appearing larval gizzard shad and perhaps other planktivores contributes to low zooplankton densities ( $<100$ zooplankters/L), compromising the success of larval bluegills in reservoirs.

\section{Management Implications}

We agree with DeVries and Stein (1990) that stocking threadfin and gizzard shad as supplemental forage for piscivorous sportfish can have deleterious effects on resident species with planktivorous larvae and should be considered cautiously. In systems with either shad species, several management options are available. As with other fishes (see Ney 1996; Maceina et al. 1996 for reviews), larval gizzard shad abundances are positively related to total phosphorus and turbidity (Stein et al. 1996; Bremigan 1997), reinforcing the perspective that sportfish, such as bluegills, should do less well in hypereutrophic reservoirs, such as Kokosing Lake, Clark Lake, and Stonelick Lake, as we have documented. In addition, rising water levels during spring foster high peak densities of gizzard shad, whereas warm temperatures improve growth (Michaletz 1997). Because environmental characteristics probably dictate abundance and thereby the impact of gizzard shad, managing these systems through watershed improvement (Addis and Les 1996; Stein et al. 1996) should reduce factors such as productivity (via reduction of phosphorus), turbidity (through reduced sediment load), and spring water level fluctuations (by controlling reservoir water level), ultimately reducing peak densities of shad as well as total shad biomass in reservoirs. Released from planktivory, zooplankton should often be abundant, improving success of other planktivorous larvae such as bluegills (Stein et al. 1996).

As a supplement to watershed improvement, sportfish populations could be managed to mitigate effects of threadfin shad or gizzard shad. In many fishes, increasing adult body size may lead to early spawning (Willis 1987; Miranda and Muncy 1988; Goodgame and Miranda 1993). Early hatched larvae produced by large adults may appear before or during dates that peak densities of gizzard shad and threadfin shad occur. Hence, protecting large spawning adults (i.e., through size limits) might increase the likelihood of larval success by improving the likelihood that larvae appear when zooplankton is abundant. Though stocking limnetic piscivores (see Dettmers et al. 1996 for review) could reduce juvenile threadfin shad or gizzard shad densities, juvenile shad often remain at densities sufficiently high to deplete zooplankton ( $\sim 95 \%$ of Ohio reservoirs; Dettmers et al. 1996). Thus, stocking predators without watershed improvement is probably a limited option for reducing the deleterious effects of gizzard shad on resident sportfishes.

\section{Acknowledgments}

We thank the faculty, graduate students, and technicians of the Aquatic Ecology Laboratory for insightful comments and many hours of volunteer support. The efforts of N. Dingledine, N. Donovan, J. Eckert, D. Lozier, M. Puleo, S. Strong-Betz, H. Thomas, and, especially, B. Thompson were invaluable to this research. We also thank J. Stafford and his staff at the Hebron State Fish Hatchery for their generous support. Comments by P. Curtis, D. DeVries, E. Marschall, M. Ridgway, D. Stouder, and two anonymous reviewers contributed substantially to the manuscript. R. Wright provided much sound advice during the analysis and writing stage. This research was funded by National Science Foundation grants DEB 9407859 and DEB 9107173 to R.A.S and Federal Aid in Sport Fish Restoration, project F-69-P, administered jointly by the U.S. Fish and Wildlife Service and the Ohio Division of Wildlife. A Presidential Fellowship from The Ohio State University supported J.E.G during part of this research.

\section{References}

Addis, J. T., and B. L. Les. 1996. Expanding perspectives on gaining public support for management. Pages 42-46 in L. E. Miranda and D. R. DeVries, editors. Multidimensional approaches to reservoir fisheries management. American Fisheries Society, Symposium 16, Bethesda, Maryland.

Alford, R. A., and H. M. Wilbur. 1985. Priority effects in experimental pond communities: competition between Bufo and Rana. Ecology 64:1097-1105.

Allen, M. S., and D. R. DeVries. 1993. Spatial and temporal heterogeneity of larval shad in a large impoundment. Transactions of the American Fisheries Society 122:1070-1079. 
Bettoli, P. W., M. J. Maceina, R. L. Noble, and R. K. Betsill. 1992. Piscivory in largemouth bass as a function of aquatic vegetation abundance. North American Journal of Fisheries Management 12: 509-516.

Blaxter, J. H. S. 1974. The early life history of fish. Springer-Verlag, Berlin.

Blaxter, J. H. S. 1986. Development of sense organs and behavior of teleost larvae with special reference to feeding and predator avoidance. Transactions of the American Fisheries Society 115:98-114.

Bremigan, M. T. 1997. Variable recruitment of gizzard shad, a strong interactor in reservoirs: exploring causal mechanisms and implications for food webs. Doctoral dissertation, Ohio State University, Columbus.

Bremigan, M. T., E. M. Lewis, M. B. Jones, R. A. Stein, and D. R. DeVries. 1991. Evaluating the effects of stocking threadfin shad on young-of-year crappie, bluegill, and largemouth bass in Ohio lakes. Ohio Department of Natural Resources, Federal Aid in Sport Fish Restoration, F-57-R-13, Final Performance Report, Columbus, Ohio.

Buynak, G. L., R. S. Hale, and B. Mitchell. 1992. Differential growth of young-of-year gizzard shad in several Kentucky reservoirs. North American Journal of Fisheries Management 12:656-662.

Confer, J. L., and G. L. Lake. 1987. Influence of prey type on growth of young yellow perch (Perca flavescens). Canadian Journal of Fisheries and Aquatic Sciences 44:2028-2033.

Connell, J. H. 1983. On the prevalence and relative importance of interspecific competition: evidence from field experiments. American Naturalist 111: 1119-1144.

Crowder, L. B., and H. L. Crawford. 1984. Ecological shifts in resource use by bloaters in Lake Michigan. Transactions of the American Fisheries Society 113: 694-700.

Culver, D. A., M. M. Boucherle, D. J. Bean, and J. W. Fletcher. 1985. Biomass of freshwater crustacean zooplankton from length-weight regressions. Canadian Journal of Fisheries and Aquatic Sciences 42:1380-1390.

Davies, W. D., B. W. Smith, and W. L. Shelton. 1979 Predator-prey relationships in management of small impoundments. Pages 449-458 in H. Clepper, editor. Predator-prey systems in management of small impoundments. Sport Fishing Institute, Washington, D.C.

Dettmers, J. M., D. R. DeVries, and R. A. Stein. 1996. Quantifying responses to hybrid striped bass predation across multiple trophic levels: implications for reservoir biomanipulation. Transactions of the American Fisheries Society 125:491-504.

Dettmers, J. M., and R. A. Stein. 1992. Food consumption by larval gizzard shad: zooplankton effects and implications for reservoir communities. Transactions of the American Fisheries Society 121: 494-507.

Dettmers, J. M., and R. A. Stein. 1996. Quantifying linkages among gizzard shad, zooplankton, and phytoplankton in reservoirs. Transactions of the American Fisheries Society 125:27-41.

DeVries, D. R., and R. A. Stein. 1990. Manipulating shad to enhance sport fisheries in North America: an assessment. North American Journal of Fisheries Management 10:209-223.

DeVries, D. R., and R. A. Stein. 1991. Comparison of three zooplankton samplers: a taxon-specific assessment. Journal of Plankton Research 13:53-59.

DeVries, D. R., and R. A. Stein. 1992. Complex interactions between fish and zooplankton: quantifying the role of an open-water planktivore. Canadian Journal of Fisheries and Aquatic Sciences 49:12121227.

DeVries, D. R., R. A. Stein, J. G. Miner, and G. G. Mittelbach. 1991. Stocking threadfin shad: consequences for young-of-year fishes. Transactions of the American Fisheries Society 120:368-381.

Donovan, N. S., R. A. Stein, and M. W. White. 1997. Enhancing percid stocking success through an understanding of age-0 piscivore-prey interactions in reservoirs. Ecological Applications 7:1311-1329.

Duffy, J. T., C. E. Epifanio, and J. S. Cope. 1996. Effects of prey density on growth and mortality of weakfish Cynoscion regalis (Bloch and Schneider) larvae: experiments in field enclosures. Journal of Experimental Marine Biology and Ecology 202:191-203.

Dumont, H. J., I. Van de Velde, and S. Dumont. 1975. The dry weight estimates of biomass in selection of Cladocera, Copepoda and Rotifera from the plankton, periphyton, and benthos of continental waters. Oecologia 19:75-97.

Eldridge, M. B., J. A. Whipple, D. England, M. J. Bowers, and B. M. Jarvis. 1981. Effects of food and feeding factors on laboratory-reared striped bass larvae. Transactions of the American Fisheries Society 110:111-120.

Frank, K. T., and W. C. Leggett. 1994. Fisheries ecology in the context of ecological and evolutionary theory. Annual Review of Ecology and Systematics 25: 401-422.

Garvey, J. E., N. A. Dingledine, N. S. Donovan, and R. A. Stein. 1998a. Exploring spatial and temporal variation within reservoir food webs: predictions for fish assemblages. Ecological Applications 8:104120.

Garvey, J. E., E. A. Marschall, and R. A. Wright. 1998b. From star charts to stoneflies: detecting relationships in continuous bivariate data. Ecology 79:442447.

Garvey, J. E., and R. A. Stein. 1998. Linking bluegill and gizzard shad assemblages to growth of age-0 largemouth bass in reservoirs. Transactions of the American Fisheries Society 127:70-83.

Gilliam, J. F. 1982. Habitat use and competitive bottlenecks in size-structured fish populations. Doctoral dissertation. Michigan State University, East Lansing.

Goodgame, L. S., and L. E. Miranda. 1993. Early growth and survival of age-0 largemouth bass in relation to parental size and swim-up time. Transactions of the American Fisheries Society 122:131-138. 
Guest, W. C., R. W. Drenner, S. T. Threlkeld, F. D. Martin, and J. D. Smith. 1990. Effects of gizzard shad and threadfin shad on zooplankton and young-ofyear white crappie production. Transactions of the American Fisheries Society 119:529-536.

Hodge, S., W. Arthur, and P. Mitchell. 1996. Effects of temporal priority on interspecific interactions and community development. Oikos 76:350-358.

Hunter, J. R. 1981. Feeding ecology and predation of marine fish larvae. Pages 33-79 in R. Lasker, editor. Marine fish larvae. Washington Sea Grant, University of Washington Press, Seattle.

Jenkins, R. M. 1955. The effect of gizzard shad on the fish population of a small Oklahoma lake. Transactions of the American Fisheries Society 85:5874.

Johnson, T. B., and J. F. Kitchell. 1996. Long-term changes in zooplanktivorous fish community composition: implications for food webs. Canadian Journal of Fisheries and Aquatic Sciences 53:27922803.

Kashuba, S. A., and W. J. Matthews. 1984. Physical condition of larval shad during spring-summer in a southwestern reservoir. Transactions of the American Fisheries Society 113:199-204.

Keast, A., and J. M. Eadie. 1985. Growth depensation in year-0 largemouth bass: the influence of diet. Transactions of the American Fisheries Society 114: 204-213.

Kirk, J. P., W. D. Davies, and K. Park. 1986. Response of some members of the fish community to gizzard shad removal from Chambers County Public Fishing Lake, Alabama. North American Journal of Fisheries Management 6:252-255.

Kneib, R. T. 1993. Growth and mortality in successive cohorts of fish larvae within an estuarine nursery. Marine Ecology Progress Series 94:115-127.

Leggett, W. C., and E. DeBlois. 1994. Recruitment in marine fishes: is it regulated by starvation and predation in the egg and larval stages? Netherlands Journal of Sea Research 32:119-134.

Letcher, B. H., J. A. Rice, L. B. Crowder, and F. P. Binkowski. 1996. Size-dependent effects of continuous and intermittent feeding on starvation time and mass loss in starving yellow perch larvae and juveniles. Transactions of the American Fisheries Society 125:14-26.

Li, S., and J. A. Mathias. 1982. Causes of high mortality among cultured larval walleyes. Transactions of the American Fisheries Society 111:710-721.

Luecke, C., J. A. Rice, L. B. Crowder, S. F. Ye, and F. P. Binkowski. 1990. Recruitment mechanisms of bloater in Lake Michigan: an analysis of the predatory gauntlet. Canadian Journal of Fisheries and Aquatic Sciences 47:524-532.

Maceina, M. J., and five coauthors. 1996. Compatibility between water clarity and quality black bass and crappie fisheries in Alabama. Pages 296-305 in L. E. Miranda and D. R. DeVries, editors. Multidimensional approaches to reservoir fisheries management. American Fisheries Society, Symposium 16, Bethesda, Maryland.
Matthews, W. J. 1984. Influence of turbid inflows on vertical distribution of larval shad and freshwater drum. Transactions of the American Fisheries Society 113:192-198.

Michaletz, P. H. 1997. Factors affecting abundance, growth, and survival of age-0 gizzard shad. Transactions of the American Fisheries Society 126:84100.

Miller, T. J., L. B. Crowder, J. A. Rice, and E. A. Marschall. 1988. Larval size and recruitment mechanisms in fishes: toward a conceptual framework. Canadian Journal of Fisheries and Aquatic Sciences 45:1657-1670.

Miranda, L. E., and R. J. Muncy. 1988. Spawning sequence of largemouth bass, bluegill, and gizzard shad. Proceedings of the Annual Conference Southeastern Association of Fish and Wildlife Agencies 41(1987):197-204.

Mooij, W. M. 1996. Variation in abundance and survival of fish larvae in shallow eutrophic Lake Tjeukemeer. Environmental Biology of Fishes 46:265279.

Mundahl, N. D. 1991. Sediment processing by gizzard shad, Dorosoma cepedianum (LeSueur), in Acton Lake, Ohio, U.S.A. Journal of Fish Biology 38:565572.

Mundahl, N. D., and T. E. Wissing. 1988. Selection and digestive efficiencies of gizzard shad feeding on natural detritus and two laboratory diets. Transactions of the American Fisheries Society 117:480487.

Ney, J. J. 1996. Oligotrophication and its discontents: effects of reduced nutrient loading on reservoir fisheries. Pages 285-295 in L. E. Miranda and D. R. DeVries, editors. Multidimensional approaches to reservoir fisheries management. American Fisheries Society, Symposium 16, Bethesda, Maryland.

Noble, R. L. 1975. Growth of young yellow perch (Perca flavescens) in relation to zooplankton populations. Transactions of the American Fisheries Society 104:731-743.

Olson, M. H. 1996. Ontogenetic niche shifts in largemouth bass: variability and consequences for firstyear growth. Ecology 77:179-190.

Olson, M. H., G. G. Mittelbach, and C. W. Osenberg. 1995. Competition between predator and prey: resource-based mechanisms and implications for stage-structured dynamics. Ecology 76:1758-1771.

Persson, L. 1988. Asymmetries in competitive and predatory interactions in fish populations. Pages 203218 in B. Ebenman and L. Persson, editors. Sizestructured populations: ecology and evolution. Springer-Verlag, Berlin.

Persson, L., and L. A. Greenberg. 1990. Juvenile competitive bottlenecks: the perch (Perca fluviatilis)roach (Rutilus rutilus) interaction. Ecology 71:4456.

Pope, K. L., and D. R. DeVries. 1994. Interactions between larval white crappie and gizzard shad: quantifying mechanisms in small ponds. Transactions of the American Fisheries Society 123:975-987.

Press, W. H., S. A. Teukolsky, W. T. Vetterling, and B. 
P. Flannery. 1992. Numerical recipes in C: the art of scientific computing. Cambridge University Press, New York.

Prout, M. W., E. L. Mills, and J. L. Forney. 1990. Diet, growth, and potential competitive interactions between age- 0 white perch and yellow perch in Oneida Lake, New York. Transactions of the American Fisheries Society 119:966-975.

Rice, J. A., L. B. Crowder, and F. P. Binkowski. 1987. Evaluating potential sources of mortality for larval bloater (Coregonus hoyi): starvation and vulnerability to predation. Canadian Journal of Fisheries and Aquatic Sciences 44:467-472.

Ricker, W. E. 1975. Computation and interpretation of biological statistics of fish populations. Fisheries Research Board of Canada Bulletin 191.

Rudstam, L. G., R. C. Lathrop, and S. R. Carpenter. 1993. The rise and fall of a dominant planktivoredirect and indirect effects on zooplankton. Ecology 74:303-319.

SAS Institute. 1985. SAS users guide: statistics, version 5 edition. SAS Institute, Cary, North Carolina.

Schoener, T. W. 1983. Field experiments of interspecific competition. American Naturalist 122:240-279.

Shelton, W. L., C. D. Riggs, and L. G. Hill. 1982. Comparative reproductive biology of the threadfin shad and gizzard shad in Lake Texoma, Oklahoma-Texas. Pages 47-51 in C. F. Bryan, J. V. Conner, and F. M. Truesdale, editors. The fifth annual larval fish conference. Louisiana State University, Louisiana Cooperative Fisheries Research Unit and the School of Forestry and Wildlife Management, Baton Rouge.

Smock, L. A. 1980. Relationships between body size and biomass of aquatic insects. Freshwater Biology 10:375-383.

Sredl, M. J., and J. P. Collins. 1991. The effect of ontogeny of interspecific interactions in larval amphibians. Ecology 72:2232-2239.
Stahl, T. P., and R. A. Stein. 1994. Influence of larval gizzard shad (Dorosoma cepedianum) density on piscivory and growth of young-of-year saugeye (Stizostedion vitreum $\times S$. canadense). Canadian Journal of Fisheries and Aquatic Sciences 51:19932002.

Stein, R. A., M. T. Bremigan, and J. M. Dettmers. 1996. Understanding reservoir systems with experimental tests of ecological theory: a prescription for management. Pages 12-22 in L. E. Miranda and D. R. DeVries, editors. Multidimensional approaches to reservoir fisheries management. American Fisheries Society, Symposium 16, Bethesda, Maryland.

Stein, R. A., D. R. DeVries, and J. M. Dettmers. 1995. Food web regulation by a planktivore: exploring the generality of the trophic cascade hypothesis. Canadian Journal of Fisheries and Aquatic Sciences $52: 2518-2526$.

Timmons, T. J., W. L. Shelton, and W. D. Davies. 1980. Differential growth of largemouth bass in West Point Reservoir, Alabama-Georgia. Transactions of the American Fisheries Society 109:176-186.

Welker, M. T., C. L. Pierce, and D. H. Wahl. 1994. Growth and survival of larval fishes: roles of competition and zooplankton abundance. Transactions of the American Fisheries Society 123:703-717.

Werner, R. G., and J. H. S. Blaxter. 1980. Growth and survival of larval herring (Clupea harengus) in relation to prey density. Canadian Journal of Fisheries and Aquatic Sciences 37:1063-1069.

Willis, D. W. 1987. Reproduction and recruitment of gizzard shad in Kansas reservoirs. North American Journal of Fisheries Management 7:71-80.

Ziebell, C. D., J. C. Tash, and R. L. Barefield. 1986. Impact of threadfin shad on macrocrustacean zooplankton in two Arizona lakes. Journal of Freshwater Ecology 3:399-406.

Received June 19, 1997 Accepted March 12, 1998 